\title{
INTERCULTURAL CONCEPT OF GLOBAL PRODUCTS
}

\author{
Miroslava Heczková, Michal Stoklasa
}

\section{Klíčová slova:}

globalizace, globální marketing, interkulturní marketing, globální produkty, standardizace, adaptace, marketingový mix

\section{Key words:}

globalization, global marketing, intercultural marketing, global products, standardization, adaptation, marketing mix

\begin{abstract}
Abstrakt
Obsahem článku je charakteristika a vymezení pojmu globalizace s přihlédnutím k rozdílům v pojetí globálního a interkulturního marketingu. Popisuje výhody a nevýhody globalizace ve vztahu k podniku, možnosti uplatňování standardizace či adaptace. Stěžejní částí je nastínit interkulturní přístup ke globálním produktům pro podniky střední a malé. V závěru předkládají autoři možnosti použití, kde navrhují postup, jak mohou podniky bez dostatečného know-how využít tuto teorii v praxi.
\end{abstract}

\begin{abstract}
The article is to characterize and determine the concept of globalization while considering the differences in the theories of global and intercultural marketing. It describes the advantages and disadvantages of globalization in relation to the company, possibilities of application of standardization or adaptation. The fundamental part is to outline the intercultural approach to global products for middle and small sized companies. At the end of the article authors propose a case study describing the aforementioned theory on a general example.
\end{abstract}

\section{Introduction}

Machková (2006) divides products into domestic, export, multinational and global ones. "Global products are those which are not bound to social-cultural differences (cultureunbound products) and come out from the uniformity of needs on the market. These types of products are conceived for the broadest segments of customers and are entirely standardized (e.g. Pepsi - Coca Cola, American chewing gum, consumer electronics, etc.). The only adaptation of these products is the translation of manuals and packaging (Machková, 2006, p. 118)." Based on the definition it is obvious that these products are mainly produced by large companies.

The opposite of global companies and global products are local (national) companies. These companies have to face increase in competition from companies operating on international markets. If they want to ensure the viability, they have to be flexible to adapt to new tendencies in globalization. There are basically two ways of how to deal with the process of globalization. The first (easier) one is to monitor systematically the effects of globalization and to adapt continuously to own activities. The second way is disproportionately more difficult but with higher potential, that is, to get actively involved in globalization and to start doing business abroad (Světlík, 2003). 
This article aims at defining and characterizing the concept of globalization in relation to a company and at outlining an intercultural approach to global products for small and medium enterprises.

\section{Globalization, global and intercultural marketing}

The concept of globalization was first used by the American economist Theodore Levitt in 1985 to describe the development of world economy in the previous decade (Kislingerová, Nový, 2004). The term has become "overused" in time and many new definitions have been created since. Every author focuses on a different aspect of globalization and approaches this issue differently.

Many of the definitions agree on the basis that the term globalization is actually the collective name for a set of interrelated economic, ideological, technological and cultural changes (Jeníček, 2002). The economic changes include internationalization of production, capital mobility, economic interdependence and others. Because of these changes new effects can be observed such as: spread of the standardized goods across the globe, the increased mobility of labour, reorganization of production and mutual penetration of sectors across borders. The ideological changes include privatization, deregulation, liberalization of trade and investments. The major technological changes in information and communication technologies are evolving at a fast pace and reduce distances on the Earth. The shift from production of goods to production of services comes coupled with it. Cultural changes create a unified society based on the same principles, habits and shopping habits. If all these changes are put together, then the evolution towards universal world civilization, which is not limited by place or time, is evident (Huntington, 2001).

How globalization has changed lives of customers can be described on an example of a very well-known sector - tourism. Globalization has changed the nature of tourism, both on the side of the supply as well as the demand. Countries struggle with economic and demographic changes and that means a change for tourist destinations as well. These have changed thanks to globalization into uniform places with the same architecture, products, culture and the lifestyle of local citizens. In each of these destinations the same buildings of multinational companies, fast-food chains, hotels, gas stations, restaurants and other providers of services or dealers can be found. All of these are forced to maintain the same corporate identity for the whole world and thus change the face of those destinations into a unified look. Even though tourism includes many other sectors (transportation, accommodation, catering, etc.) and should be unique in every place where a tourist is, it may well be that due to global standardization that the resorts in France and Caribbean are the same and a tourist cannot tell the difference (Mowforth, Munt, 2003).

For business activities on the globalized market it is necessary to follow the principle "think global, act local". In other words, the producer must always bear in mind that globalization does not mean the same taste everywhere. Despite all the convergence of cultures local habits and customs are often defended against globalization (Nový, 2004). That is why it is necessary to distinguish between the concepts of global and intercultural marketing.

The difference in the approach of global marketing is the business orientation of a company towards markets and related planning activities. In this concept the company perceives the world (including its home market) as one market and segmentation is not focused on national borders anymore. The transition from international marketing to global marketing often 
happens when the company starts earning more than a half of its income from abroad (Cateora, Graham, 2007). But global marketing does not mean that the company has to enter every market in the world. The decision to enter the foreign market depends entirely on company's resources and the nature of threats and opportunities that are awaiting there (Kauerová, 2003).

According to Štrach "companies become international for various reasons - defensive as well as offensive (Štrach, 2009, p. 34)." Defensive (reactive) reasons for international expansion are competitive pressure, business barriers, regulations and restrictions, etc. Offensive (proactive) reasons are often driven by economy of scale, access to a foreign market, access to limited resources and investment incentives (Štrach, 2009).

The approach of intercultural marketing is equally based on globalization as well as localization. Thus the basic principle is to adapt the product and the marketing strategy to various local customer needs, but still having the global strategy in mind. It can then be said that it is trying to find the balance in differences across cultures that require local adaptation and similarities of those cultures which enable the company to have the profit thanks to economy of scale (Usunier, Lee, 2005). So on one hand there is a standardized product of global marketing and on the other there is an intercultural product that needs to be "tweaked" (adapted) to become world-wide. These products are usually designed in a way that allows easy adaptation to the needs of the target market. Compared with marketing on a national level the differences are mainly in the variables of the environment of each market. "Intercultural marketing is the theory and the research on consumer behaviour in countries with different national culture. It explains how purchasing behaviour is influenced by practices, stereotypes and prejudices of a particular national or ethnic community and how it needs to respond to such specificity in the supply and promotion of certain goods (Prücha, 2010, p. 18).“

\section{Positives and negatives of globalization for companies}

The irreversible process of globalization that penetrates all spheres of life in our society brings some concerns. The new global society is worried about the approach of multinational companies and their products to final customers.

Positive aspects of globalization certainly include reduction of costs through economy of scale. With the division of labour in the production process among multiple countries, companies are able to achieve the greatest possible savings and raise the virtual purchasing power. This division of labour thus includes even local companies which are then able to benefit from globalization. This increases their competitiveness and overall competitiveness of the region (the macro-region). The resulting product is often better because it must meet global standards. Thanks to the involvement of several companies the development is faster and the design is adjusted so it can be produced in any manufacturing factory anywhere in the world. This ensures that customers' needs are better satisfied, whether it is the range of services or the firm's ability to meet these needs anywhere in the world (Dlouhá, Dlouhý, Mezřický, 2006). It is thus clear that the process of globalization may involve not only large but also medium and small businesses.

The entry of the multinational company Hyundai into the Moravian-Silesian region is the reallife example. Thanks to this location in Eastern Europe, the company can build cars cheaper (closer to the customer, cheaper labour). Its local suppliers (SMEs), although not involved in 
the design of the final car, utilize knowledge of the technological giant. The massive investment and the increase in employment increased competitiveness of the region. By standardizing its product can be produced in any similar production facility (e.g. exhaust can be produced in six factories in the region according to current needs). A local customer receives a world-class product with factory services (e.g. almost no waiting time for spare parts) and worldwide service network.

But globalization has also many negative effects which are often pointed out. It is coupled with the risk of losing political control over the economy of a country or a region. Excessive speculative investment liberalization can have severe consequences for entire regions. The vision of getting rich quickly leads multinational companies to abuse whole countries. This is coupled with the problem that globalization is not associated with any scale of values, order, the world renowned authority or power. Global companies are not regulated in a wide range of activities by anyone. If a country starts defending itself with strict quotas or law to protect its market, its citizens or the environment, the company simply moves elsewhere where its actions are not regulated. Local suppliers are often demotivated by the centralization of decision making and their inability to influence the development of a product. Managing such a large company is challenging and can mean possible higher costs (Nezval, 2004).

The excessive standardization of products is the threat to globalization because the product is then unable to satisfy any customer. The standardization of the whole marketing mix then creates uniform marketing which utterly fails when customers are in any way different.

Globalization threatens the healthy development of national cultures because it forces them to merge with other cultures. This can lead to"resistance"against globalization through localization or regionalization. The enemies of globalization draw attention to the fact that the part of the society will benefit from it, while the other part lives in poverty because of it. This is due to rationalization of production, which lowers wages, increases unemployment, reduces the income tax of countries, which effectively undermines any concept of the welfare state and makes huge differences in the income of citizens (Dlouhá, Dlouhý, Mezrrický, 2006). All this leaves the space for an intercultural approach which takes into account local specifics and develops products accordingly.

\section{Standardization versus adaptation in marketing}

Whenever intercultural and global marketing is mentioned it is also necessary to take into account standardization and adaptation. Historically, these terms developed in the following way. In the 70 s of the $20^{\text {th }}$ century marketers argued whether adaptation or standardization was better in marketing segmentation. In the 80 s the debate moved on to the issue of globalization versus localization and in the $90 \mathrm{~s}$ to global integration versus the local responsibility. Currently the subject of the dispute lies in the fact whether the global convergence of consumer tastes makes room for global standardization of marketing mix (Cateora, Graham, 2007).

Standardization means that any customer will receive the same anytime and anywhere. At first standardization only concerned products, but it gradually spread to brand standardization which concerns the brand name, packaging and positioning of a company (Celer, 2010). In time even standardization of the whole marketing mix occurred, that means using the same product, the price, the place and promotion in all countries the company does business in. This approach, however, has the limitation of being ineffective in some countries. The 
theoretical approaches that mainly use standardization are global marketing and euro marketing.

Adaptation is used by companies holding the opinion that there is a lack of evidence of homogenization of needs, i.e. people have not created the global society and the differences still exist. Adaptation uses the typical characteristics of a market, adapts international operations and looks at marketing processes in various countries individually. Adapting the marketing mix to needs of every country brings higher costs, but also higher potential for the increased profit. Theoretical approaches for adaptation are intercultural and local marketing.

The question whether to do standardize or adapt marketing programs in each country is very common and there are numerous studies that argue in the favour of one or the other approach. The Table 1 summarizes general advantages of standardization compared to adaptation (Kauerová, 2003).

Table 1

Standardization versus adaptation

\begin{tabular}{|r|r|}
\hline \multicolumn{2}{|l|}{ Factors favouring standardization } \\
\hline$\bullet$ & Large savings in production \\
\hline$\bullet$ & Savings in research and development of a product \\
\hline$\bullet$ & Savings on sale \\
\hline - & "Reduction" of the global market - integration \\
\hline Factors favouring adaptation \\
\hline - & Broader conditions of use \\
\hline - & Government regulatory influence \\
\hline - & Various consumer behaviour models \\
\hline - & Local competitiveness \\
\hline - & Compliance with the marketing concept \\
\hline
\end{tabular}

Source: Kauerová, (2003), p. 69

\section{Intercultural approach to global products}

From previous chapters it is already clear that standardization is advantageous only in certain cases and the company should rather adapt according to various needs of a foreign market. But it is not wise to perceive these two approaches strictly. Some companies use standardized technology and adapted design (e.g. for electronics). Even such global products, which McDonalds produces, must adapt to the local taste. For example it is not possible to sell classic beef BigMac in India where cows are holy, or pork McCountry in Islamic countries where consumption of pork is forbidden. It is necessary to use different dressing for Tokio, Paris or New York. And these are just differences in the product; other elements of marketing mix differ as well, even though BigMac is considered the most global product of them all. For comparison its price in Norway 5,79 USD and in Russia 1,73 (The Economist, 2010). In this chapter authors will describe how to adapt particular elements of marketing mix according to local taste. This opens up possibilities for small and medium sized enterprises in the field of intercultural approach, through their local know-how and flexibility. 


\section{Product}

The enterprise may attempt to penetrate foreign markets with the same product as it sells on its domestic market that strategy is usually not successful due to many differences. Kotler (Kotler, Keller, 2007) mentions 5 strategies by Keegan for adaptation of a product for the foreign market:

- Direct expansion literally means direct export of a product to a foreign country without any adaptation. It can be used for electronics. Some products may encounter some difficulties (e.g. dishes - different national meals require different dishes) which can be easily solved though. Some products cannot use this strategy at all (e.g. food in general because of the different taste).

- Adaptation of a product according to different preferences or requirements of a country of sale. Based on the size of the territory that the product is adapted to we can distinguish several adaptation approaches. The smallest one is city adaptation that focuses only on one city (e.g. T-shirts "I Love New York" have originally been sold only in New York, a special type of beer for Ostrava, etc.). Larger one is the country adaptation (e.g. Ikea sells the same furniture but in different sizes for the USA and Japan). The region adaptation is the largest when companies produce products for Western Europe, Eastern Europe, Scandinavia, etc. Different than the territory adaptation would be the adaptation for different retail chains. The obligation is the adaptation of the product to existing standards and regulations of a country.

- Another form of adaptation is the adaptation of not only the product but everything that is connected with it. It can be viewed as a part of differentiation of the positioning. Consumers in different countries not only value the product differently, but also consume it in a different way.

- The so-called dual adaptation is an adaptation of a product and promotion connected to the product.

- The company can also deliver a completely new product for the target market. The key word here is to "deliver". It does not in fact need to be a newly developed product, but the company can use the already proven one and only "recycle" it. For example the car manufacturer Peugeot has done that at the launch of the new 207 when the old 206 was re-introduced for Eastern Europe and Latin America. For companies this is a simple way to reduce the cost by spreading the development costs in a longer term and to benefit from economy of scale. But if the company succeeds in developing a completely new product according to market needs, it can gain a big advantage (a company that would first come up with cheap food rich in proteins will address a market of one billion starving people).

Another important strategic decision is positioning, which has been already mentioned several times. Machková (2006) characterizes international positioning as a process of establishing a brand and its image (image of a company) with the goal to take selected position in the minds of customers. Positioning tries to identify (helps customer orientate in a wide range of supply on the market) and differentiate (helps to emphasize the differences between the company and its competitors).

\section{Price}

There are many possibilities for companies when setting the price at the foreign market. Global products can have a standardized price to keep the marketing mix consistent, to protect image or to avoid the risk of re-import. But it is not always possible and profitable. For example luxury products can have a distinctly different price in various countries based on the 
image perceived by the customer. In some countries the uniform price could be considered too low and would compromise the promoted image, in some it would be too high and would again not correspond with the positioning.

The process of product globalization modifies 3 classic approaches to pricing (Geuens, 2003). The cost approach, when the company sets the price according to costs of production, distribution and promotion, plus a profit margin. But this creates a risk for different price levels, i.e. places with a higher price are endangered by grey import from places with lower price. The demand approach, the price is set differently for different markets and market segments based on disposable income, value of the product for customers, image, etc. Again, there is a risk of grey import and a too high or low price in different countries. The competition price, the company sets the price based on the price of its competitors and the competitive advantage it has over them. This price is very often strongly influenced by the origin (the place of origin) of the product, goodwill - French wine, Scotch whisky, Czech beer, Swiss watches, etc.

In the previous paragraphs the issue of grey import has been mentioned. The company which sells its product cheaply in the country A may be forced to set the price in the country B at a much higher level because of a necessary technical adaptation, higher costs of promotion or more expensive distribution. But for an independent distributor it is easy to buy the product cheaply in country A and just to import it to the country B without any necessary adaptation, with a low price. For example it is the case of the car Ford Mustang in the Czech Republic. In the USA it costs the equivalent of CZK500 000,-, the official distributor sells it for CZK1 million and independent distributors sell it for CZK800 000-.

Furthermore there are several problems that need to be mentioned in the context of pricing. The first one is the danger of dumping. For many small European companies it is impossible to face the global competition which enters the market with lower prices to "conquer" it. Another problem is the nationalistic tendencies which often valorise products of local producers (Škoda cars retain higher price in the Czech Republic than any other competition). Some markets can only be penetrated with subsidised pricing. That is the case of markets with lower purchasing power of demand or markets with subsidized competition (agricultural products in the EU). Lastly the transfer prices become problematic too. These are the prices at which products are sold from one branch to another, often associated with the risk of tax evasion.

Machková in this context states that "despite the growing liberalization of international business, in a number of countries various instruments that restrict the freedom of pricing are used (Machková, 2006, p. 141)".

\section{Marketing communication}

The first step in developing the communication strategy is the evaluation of the characteristic features and benefits of the company or product, i.e. strengths that should be communicated on the foreign market. This requires constant monitoring of the environment and characteristics of a target group (Kauerová, 2003).

Companies can use standardized marketing communication for their global products. However, it is highly recommended to adapt it. Often it is necessary to slightly tweak the colours, the slogan or the content of advertising communication. Certain colours have negative associations in some countries, such as white in Japan or black in China. The slogan 
or the content of communication needs to be changed when translating into another language, based on the meaning. An example from the Czech Republic is Ikea that had issued flyers and billboards with the text "Doprodej Hoven" i.e. literally "Sale of Shit" (Špačková, 2010). How could this happen? Ikea leaves the names of products in Swedish. "Hoven" is the name of one kind of a carpet, sold mainly in a brown colour. Customers "giggled", but never bought this carpet, employees described. The advertising banner then automatically assigned the word "Sale" to the name of the product that did not sell well and Ikea wanted to get rid of the remaining pieces. This incident then resulted in re-naming the product which then started to sell well. This case is certainly not the only one, but it reminds that global companies should watch out for un-translated names, slogans and the content of communication.

The viable option for companies therefore is to use globally the same topic but to edit the individual elements according to local taste; for example the role of women in the society and subsequently their role in advertising. Some cultures allow showing a naked woman washing her hair, some only from shoulders up and in some countries it will need to be a man who is washing his hair.

Application of the global approach needs to be consistent with heterogeneous environment and dissimilar legal regulations of communication. Companies should therefore monitor the politico-legal and cultural environment. It is necessary to use different media according to the environment that the company is exporting to. Some countries respond well to the TV advertisement, some to news press advertisement and developing countries to personal selling. However, it must never be forgotten that marketing communication is not only about advertising but also about sales promotion, personal selling, public relations, direct marketing and sponsoring.

\section{Distribution}

If small and medium sized enterprises want to establish themselves through the intercultural way, distribution may be the biggest obstacle. Unlike the classical local distribution when the company sells its products only in one country, it is necessary to resolve many new problems. One of them is the need to build a headquarters for international distribution which will regulate the company offer to countries based on their demand. Furthermore, it is necessary to ensure distribution channels from the country of production to the country of consumption. Within the EU and the Schengen area, it is not a problem, but when exporting to for example China, it is necessary to fight with quotas and restrictions. Complicated may even be the distribution itself, based on the common practice in the foreign country. In the USA citizens are accustomed to be shopping in large shopping parks on the outskirts of cities, in China people like to shop in kiosks and to visit personal sellers. The selection of distribution channels needs to be considered with regards to the following aspects (Kotler, Keller, 2007):

- The level of costs for the distribution channel

- Locked-up capital in stock during transportation

- The nature of the product or product series

- Extent of inspection

- Coverage of the target market

The company must respect the specifics of local distribution channels and distribution practices which vary considerably in individual countries. Complete standardization of distribution is not possible because it needs to be differentiated. This problematic is thus also opened for applying an intercultural approach as opposed to purely global. 


\section{Possibilities of application}

Small and medium enterprises usually lack the knowledge how to implement this theory into practice. The authors provide in this chapter instructions on how SMEs can use a simplified cost-benefit analysis for their decision making, whether it is good for them to turn their local products into intercultural or global ones. Classic cost-benefit analysis would be too demanding for such companies, that is why we use only the basic principle and describe costs, then benefits, followed up with the evaluation. Figure 1 below shows a simplified model of scales with costs on the left side and benefits on the right side. Each bubble represents one item of costs or benefits, as described in the following text.

Figure 1

Scales of costs and benefits
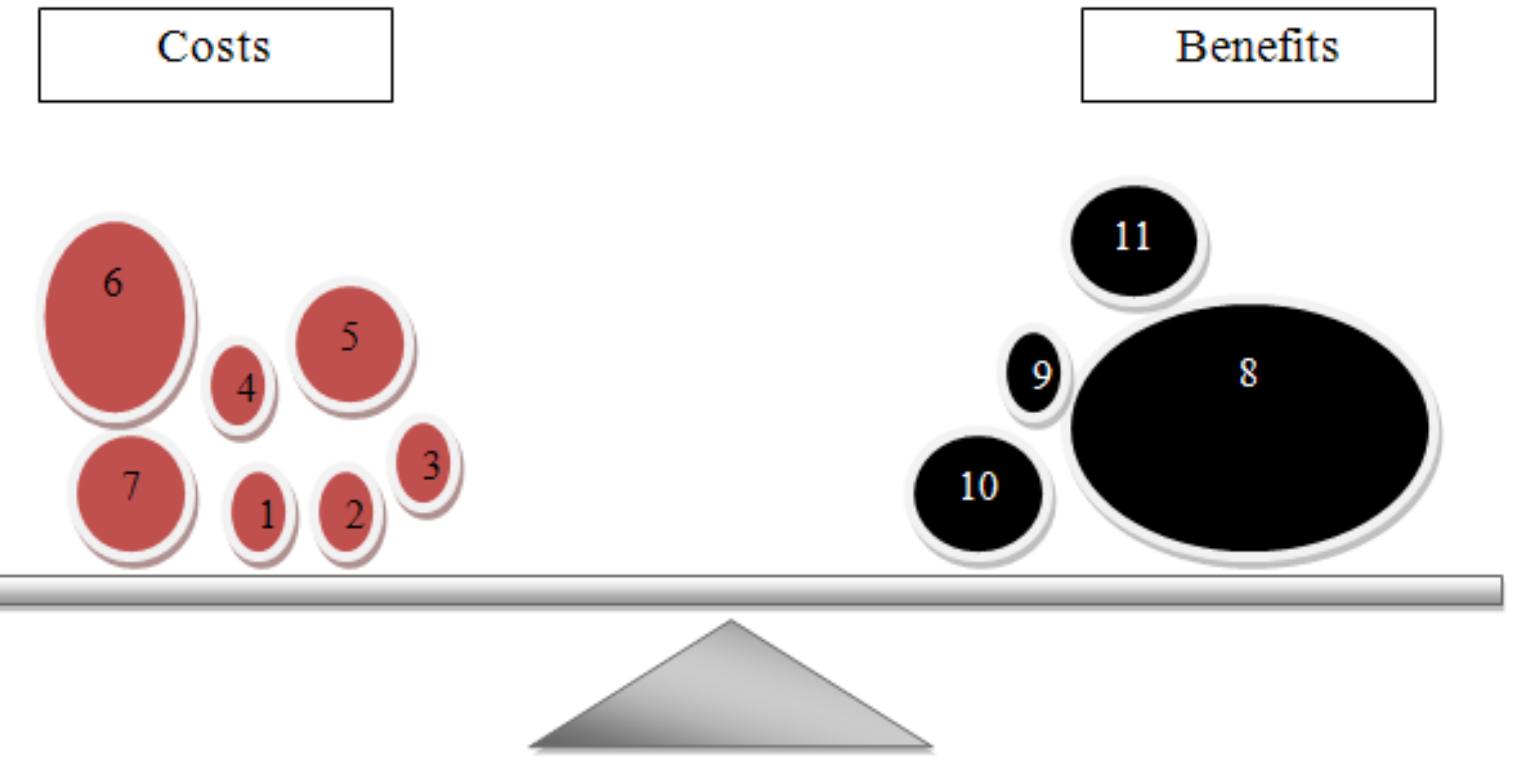

Source: author`s work

\section{Costs}

Similarly as with the sales in the home market, it is important to conduct the marketing research (1) when selling abroad. The preparation and realization of marketing strategy must be much more detailed and extensive. In addition to "standard" information which would the company research at the home market, it is necessary to obtain information about the export country and its culture, language, common practice, the economic and political situation, the import quota, the illegal structures (in Russia, South America) and other details. Furthermore, it is necessary to determine the target customer (2) in that country (positioning might differ in different countries), determine segmentation characteristics such as the age, the profession, the nationality, purchasing power, etc. These characteristics help the company to estimate the quantity of sales. Another important knowledge which can help the company to prepare before entering the foreign market is the knowledge of local habits and customs (3), i.e. how to behave during negotiations.

The rules to determine the marketing mix for the foreign market are the same as for the domestic market. The company just needs to take into account many more factors influencing each decision. The product or the product line will generally need to be adapted to foreign tastes and needs (4). The requirements for appearance, the colour, the quality or the taste need to be found out. For the successful market entry, it is necessary to verify the requirements of 
technical standards, composition and labelling of products. Overall, it is necessary to think not just about the function of the product, but mainly about the way in which the local customer will consume it. That means what design, styling, quality, additional services will be valued and required (easy installation, long warranty, financial services).

When setting the price on the foreign market the company can again use its desirable positioning - the low price to become affordable, the high price to become exclusive. It is important to be based on the price that is actually achievable on the market in that country (5). The Trade Company finds the price at which it should buy in the Czech Republic as the price achievable at the target market, less the costs of the sale and transport. The Production Company can use this simple calculation to get the maximum price at which it may produce the product in the home country.

To create the right communication mix the company should entrust it to a local agency because only then it can be properly adapted to local taste (6). When attempting to create the appropriate communication the internet might help as it is the richest and easily accessible source of information about the local style of communication.

Distribution on the foreign market can be made directly or indirectly (7). When selling directly the company itself is exporting its own products and selling them. But to manage properly direct distribution the company needs to be sufficiently linguistically equipped, to know the techniques of trade and negotiations common in the target country, and to meet local common practice in distribution to target customers. It can therefore be said that foreign trade is much more demanding than trade in the home country. Indirect distribution is the approach that uses services of business intermediaries. The company sells its product to these intermediaries and they take care of the export or sell directly to retail chains in the target country. The domestic company is then in the role of the wholesaler. Indirect distribution is advantageous if the home company doesn't have sufficient know-how to ensure the distribution itself. Indirect distribution exposes the company to considerable risks which do not need to be taken into account when distributing directly.

\section{Benefits}

New markets allow for greater total turnover and the consequent opportunity to realize greater profit (8). This is usually the main motive for expansion. Other benefits can be: the possibility to build a brand name (9), diversify product portfolio to reduce risk (10), establish partnerships, easier to get new capital, etc. In addition to many price-based benefits, there are lots of invaluable ones, such as: new employees, new partners, new challenges in new markets, know-how (11), etc.

\section{Evaluation}

The company adds up all costs and subtracts them from the anticipated benefits. If a longer time period is planned, the effect of inflation must be taken into account. Invaluable items need to be evaluated on a scale that assigns weight to negatives and positives. Finally, the company compares the state of business in which it will be without the expansion of its products (so-called zero variant) and the state, which will be reached with the use of above described procedure. Company chooses whichever side of the scales that outweighs the other one.

A practical example of small Czech company, that nearly perished until they went global, is Alwil Software with their product Avast!. In the beginning of 90`s they had a good position 
on the Czech market but with the arrival of global players everything has changed. One of the two owners of the company Eduard Kučera explains their thoughts about those times: "It was clear to us, that in order to survive, Avast! must become global product." (Němec, 2010). Nowadays the company has over 120 million users and is one of the best in their field.

\section{Conclusion}

Resulting from the characteristics of globalization and its positives and negatives is the fact that within the context of globalization both companies with the global approach as well as companies with the intercultural approach can be successful. While the purely global approach is the privilege of large (multinational) companies, small and medium sized companies can enter foreign markets by using the intercultural approach. They can even benefit from the fact that even global products differ in at least one element of marketing mix in different countries. This adaptation can be better ensured by small and medium sized companies (local ones) than large ones (multinational ones), thanks to the local knowledge. The most common practise is the standardization of the product and marketing communication with adaptation of the price and distribution (this strategy is called the mixed strategy). Adaptation of all elements of marketing mix to the local environment and individual consumers is less common.

\section{Literature}

[1] CATEORA, P.R., GRAHAM, J.L. International marketing. 13th ed. Boston, Mass.: McGraw-Hill, 2007, ISBN 0-07-308006-3.

[2] DLOUHÁ, J., DLOUHÝ, J., MEZŘICKÝ, V. Globalizace a globální problémy. Sborník textů $k$ celouniverzitnímu kurzu "Globalizace a globální problémy" 2005 - 2007. Praha: Centrum pro otázky životního prostředí UK v Praze, 2006. ISBN 80-87076-01-X

[3] HUNTINGTON, S.P. Střet civilizací. 1st ed. Praha: Rybka Publishers 2001, ISBN 80 86182-49-5.

[4] JENÍČEK, P. Globalizace světového hospodářství. 1st ed. Praha: C. H. Beck, 2002, ISBN 80-7179-787-1.

[5] KAUEROVÁ, L., VANĚK, J., VILAMOVÁ, Š. Vybraná problematika z mezinárodního marketingu. 1st ed. Ostrava: VŠB - TU, 2003, ISBN 80-248-0261-9.

[6] KISLINGEROVÁ, E., NOVÝ, I. a kol. Chování podniku v globalizujícím se prostředí. 1st ed. Praha: C. H. BECK 2005, ISBN 80-7179-847-9.

[7] KOTLER, P., KELLER, K.L. Marketing management. 12th ed. Praha: Grada Publishing, 2007, ISBN 978-80-247-1359-5.

[8] KOTLER, P., WONG, V., SAUNDERS, J., Armstrong G. Moderní marketing, Praha: Grada Publishing, 2007, ISBN 978- 80-247- 1545-2.

[9] MACHKOVÁ, H. Mezinárodní marketing. 2nd ed. Praha: Grada Publishing, 2006, ISBN 80-247-1678-X.

[10] MOWFORT, M., MUNT, I. Tourism and sustainability. 2nd ed. Taylor \& Francis eLibrary, 2003, ISBN 0-203-43729-2.

[11] NEZVAL, P. Světová ekonomika, SU OPF Karviná, 2006, ISBN 80-7248-318-8.

[12] PELSMACKER, P., GEUENS, M., BERGH, J.V. Marketingová komunikace. Praha: Grada, 2002, ISBN : 80-247-0254-1.

[13] PRUCHA, J. Interkulturní komunikace. 1st ed. Praha: Grada, 2010, ISBN 978-80-247-

3069-1.

[14] SVĚTLÍK, J. Marketing pro evropský trh. 1st ed. Praha: Grada, 2003, ISBN 80-247-

0422-6. 
[15] ŠTRACH, P., Mezinárodní management. 1st ed. Praha: Grada Publishing, 2009, ISBN 978-80-247-2987-9.

[16] USUNIER, Jean-Claude - LEE, Julie Anne. Marketing across cultures, 4th ed. Harlow: Prentice Hall, 2005, ISBN 0273685295.

[17] CELER, Č. Marketingové strategie na globálních trzích (2.). Marketingové noviny [online]. Oct 24th 2010 [cit. 2011-03-28]. Available from WWW:

$<$ http://www.marketingovenoviny.cz/index.php3?Action=View\&ARTICLE_ID=3605>.

[18] NĚMEC, J. Eduard Kučera dává software zadarmo, presto vydělává miliony. Profit [online]. Feb 23rd 2010 [cit. 2011-03-28]. Available from WWW: $<$ http://www.profit.cz/clanek/eduard-kucera-dava-software-zadarmo-presto-vydelavamiliony/>.

[19] The Economist [online]. Feb 4th 2011 [cit. 2011-03-28]. BigMac Index. Available from WWW: <http://www.economist.com/node/13055650 >.

[20] ŠPAČKOVÁ, I. Ikea nabízela „Doprodej Hoven“, kontroverzní koberce pak prejmenovala. iDnes [online]. Mar 4th 2010 [cit. 2011-03-28]. Available from WWW: $<$ http://ekonomika.idnes.cz/ikea-nabizela-doprodej-hoven-kontroverzni-koberce-pakprejmenovala-11o-/ekoakcie.aspx?c=A100304_105354_ekoakcie_spi>.

\section{Classification JEL: M31, M21}

Ing. Miroslava Heczková, Ph.D., Ing. Michal Stoklasa

Katedra marketingu

Slezská univerzita v Opavě

Obchodně podnikatelská fakulta v Karviné

Univerzitní náměstí 1934/3

Karviná

heczkova@opf.slu.cz, stoklasa@opf.slu.cz 